\title{
Fostering Diversity and Inclusion Can Be Good for Business
}

\section{Kimberly Eddleston (Northeastern University)}

\section{KEYWORDS: Family Business, human resources.}

Diversity and inclusion programs are being embraced by firms of all sizes everywhere. In this interview, family business Editor Kim Eddleston talks with Professor Michelle Duguid, who runs the Diversity, Inclusion and Belonging initiative at Cornell University, about how family businesses can become more diverse and inclusive too.

Duguid, an acclaimed diversity research scholar, discusses what research has shown about the strengths that a diverse staff brings to companies of all sizes: stronger connections with customers, better problem solving and enhanced creativity. She also shares tips on how family businesses can get started and recover gracefully from the inevitable missteps. 